\title{
Bronchopleural fistula complicating massive pulmonary infarction
}

\author{
E. R. MCFADDEN, JR. ${ }^{1}$, A N D FRA NK LUPARELLO \\ From the Department of Medicine, Mercy Hospital, Pittsburgh, Pennsylvania
}

\begin{abstract}
The clinical course of a patient who developed a lung abscess with a bronchopleural fistula following a massive infarction is described. Comparison of the events in this patient's illness with others reported in the literature reveals a recognizable syndrome which is characterized by three phases. The initial illness consists of massive infarction with its well-recognized sequelae. Following a short period of improvement, the second phase begins with the production of copious amounts of blood-tinged or purulent sputum, accompanied by fever, leucocytosis, and cardiac decompensation. This phase lasts several days to weeks and signifies excavation of the infarcted area. After another period of relative quiescence, the third phase, characterized by the abrupt onset of fever, pleuritic pain, cough, and acute dyspnoea, begins. These symptoms herald bronchopleural fistula. In view of the high mortality, prompt recognition of this syndrome and vigorous treatment appear to be mandatory.
\end{abstract}

This report describes a patient who developed a bronchopleural fistula after a massive pulmonary infarction. Review of the literature reveals only 12 other cases, many of which share the same distinctive clinical features as ours, recognition of which may have diagnostic and therapeutic importance.

\section{CASE REPORT}

A 49-year-old housewife with rheumatic heart disease was admitted to hospital for the treatment of palpitations, dyspnoea, and severe right upper quadrant abdominal pain of two days' duration.

On admission she was febrile $\left(101^{\circ} \mathrm{F} . ; 38.2^{\circ} \mathrm{C}\right.$.), tachypnoeic, and cyanotic. There was engorgement of the neck veins to the angle of the jaw, icteric sclerae, and signs of a right pleural effusion. The pulse rate was 160 per minute and irregular. A protodiastolic gallop was audible, as well as murmurs of mitral insufficiency and stenosis, and aortic insufficiency. The liver was enlarged $5 \mathrm{~cm}$. below the right costal margin and was tender. There was no evidence of thrombophlebitis.

The haemoglobin was $10 \mathrm{~g} . / 100 \mathrm{ml}$., with a haematocrit of $38 \%$. The white blood count was $15,000 / \mathrm{cu}$. mm. (92\% polymorphonuclears). Urine: ++ protein with no other abnormality. Serum glutamic oxaloacetic transaminase: 2,500 units. Total serum bilirubin: $2 \cdot 16 \mathrm{mg}$. $/ 100 \mathrm{ml}$. ; conjugated fraction $1.26 \mathrm{mg} . / 100 \mathrm{ml}$. Alkaline phosphatase: 7.25 Bodansky units. Blood urea nitrogen: $50 \mathrm{mg} . / 100 \mathrm{ml}$.

1Present address: Department of Medicine, William Beaumont General Hospital, El Paso, Texas, U.S.A.
Electrolytes, ASO titre, $\mathrm{C}$ reactive protein, and $\mathrm{PBI}$ were normal. A chest radiograph showed a right pleural effusion and cardiomegaly (Fig. 1). Atrial flutter with rapid ventricular response, right axis $\overrightarrow{\vec{B}}$ deviation, and an $R-R^{\prime}$ complex in leads $V_{1}$ to $V: 3$ was seen on the electrocardiogram. Thoracocentesis? yielded $850 \mathrm{ml}$. of sterile amber fluid with a specific gravity of 1.010 and a protein content of $1.8 \mathrm{~g}$. $100 \mathrm{ml}$. Numerous blood cultures were sterile. Scanto amounts of non-purulent sputum containing onlyo normal oral flora were produced. Pulmonary artery: catheterization and selective angiography demon- $\frac{3}{3}$ strated a filling defect in the pulmonary artery. supplying the right lower lobe and mild pulmonaryo hypertension (mean pulmonary artery pressure of $40 \mathrm{~mm} . \mathrm{Hg}$ ).

HOSPITAL COURSE Initial therapy consisted of heparin, diuretics, and digoxin. and the patient experienced both subjective and objective improvement. Her dyspnoea subsided as fever and oedema regressed. $N$ and her blood chemistry returned to normal. TheN్ tenth hospital day was marked by return of fever, $\omega$ re-accumulation of pleural fluid, and the onset of cough productive of small amounts of blood-tingede sputum. The fluid obtained from thoracocentesis was still sterile but was now a blood-stained exudate con $-?$ taining $6.9 \mathrm{~g} . / 100 \mathrm{ml}$. protein with a specific gravity of 1.017. Multiple blood cultures were also sterile우 and normal respiratory flora persisted in the sputum. There had been no change in the chest radiographs. $\frac{\vec{D}}{0}$

Over the next 13 days sputum volume began slowly to increase. By the twenty-third day, the patient was coughing copious amounts of purulent sputum and 
FIG. 1. Portable chest radiograph taken on admission shows a right pleural effusion and cardiomegaly.
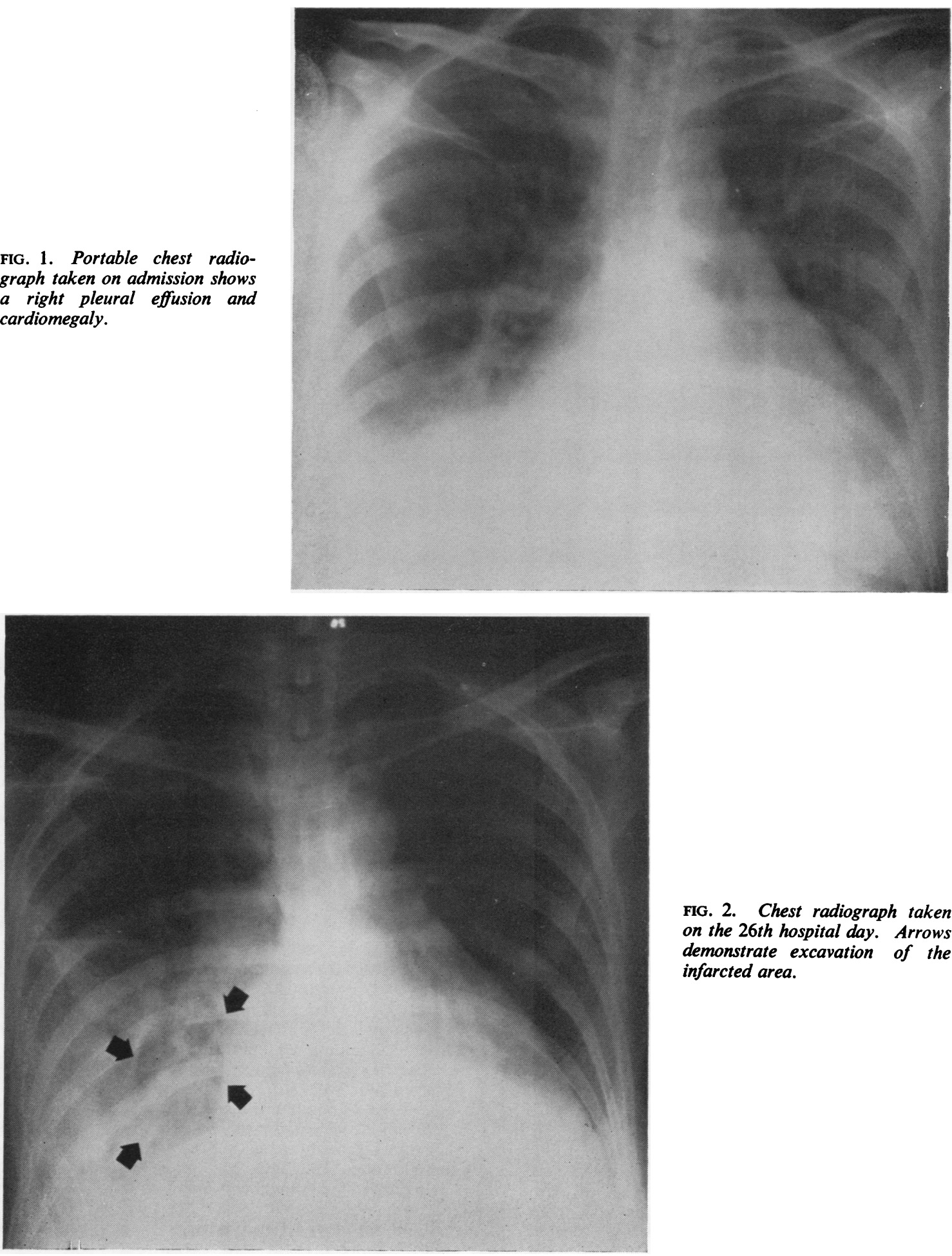

FIG. 2. Chest radiograph taken on the 26th hospital day. Arrows demonstrate excavation of the infarcted area. 


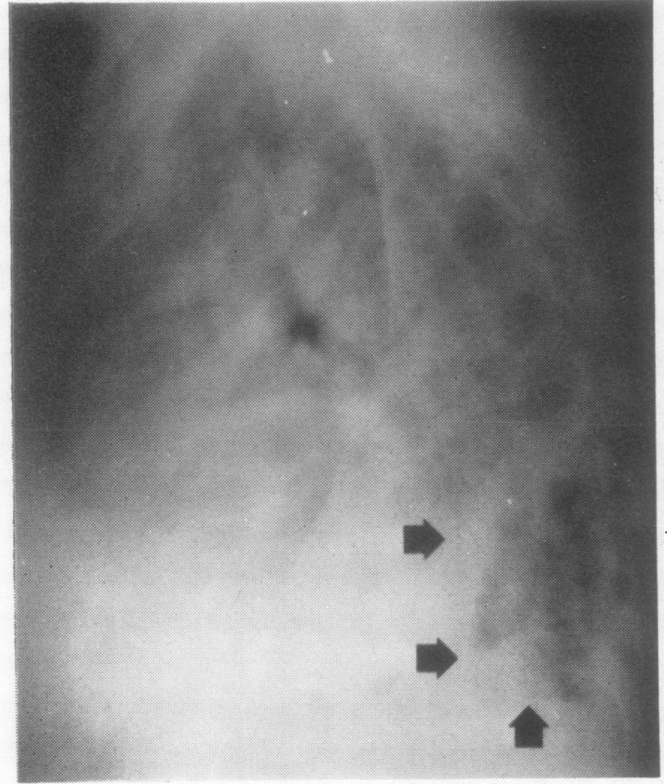

(b)

FIG. 3. Postero-anterior (a) and lateral (b) chest films demonstrating pyopneumothorax (arrows) on the 35th hospital day. her temperature rose to $102^{\circ} \mathrm{F} .\left(38 \cdot 8^{\circ} \mathrm{C}.\right)$. Coagulasepositive Staphylococcus aureus was isolated from both the sputum and thoracocentesis fluid, but blood cultures continued to be sterile. Chest radiographs disclosed a cavity in the right lower lobe (Fig. 2). (ֻ) Intravenous methicillin, $10 \mathrm{~g} . / \mathrm{day}$, was started to $\frac{\sigma}{\sigma}$ control the infection. Over the next three days the 3 . patient's course was complicated further by several episodes of acute pulmonary oedema, which responded to symptomatic therapy. As the staphylococcal infection responded to the antibiotic her fever regressed and the cardiac symptoms disappeared. Pro- $D$ gress continued to be satisfactory until the thirty-fifth hospital day, at which time acute tachypnoea and a $N$ dry intractable cough heralded a pneumothorax (Fig. 3). A closed thoracotomy with underwater drainage $\mathrm{N}$ completely expanded the lung. Contrast material $\underset{\omega}{N}$ injected into the right pleural space demonstrated a $\sigma$ bronchopleural fistula (Fig. 4). Ten days later a right lower lobectomy was performed.

The surgical specimen showed a completely in- $\mathbb{D}$ farcted lobe with a $7 \mathrm{~cm}$. cavity in the posterior peri- : phery which communicated directly with a secondary $\frac{T}{T}$ bronchus and entered the pleural space. Organized $\frac{\vec{\Phi}}{\Phi}$ thrombi were present in the arteries of the right $\cong$ lower lobe. The area had been sterilized by the $\mathbb{D}$ methicillin since microscopic and cultural evidence of infection was absent.

Eighteen days after discharge from hospital, and $\delta$ while taking digoxin and warfarin (Coumadin), the 

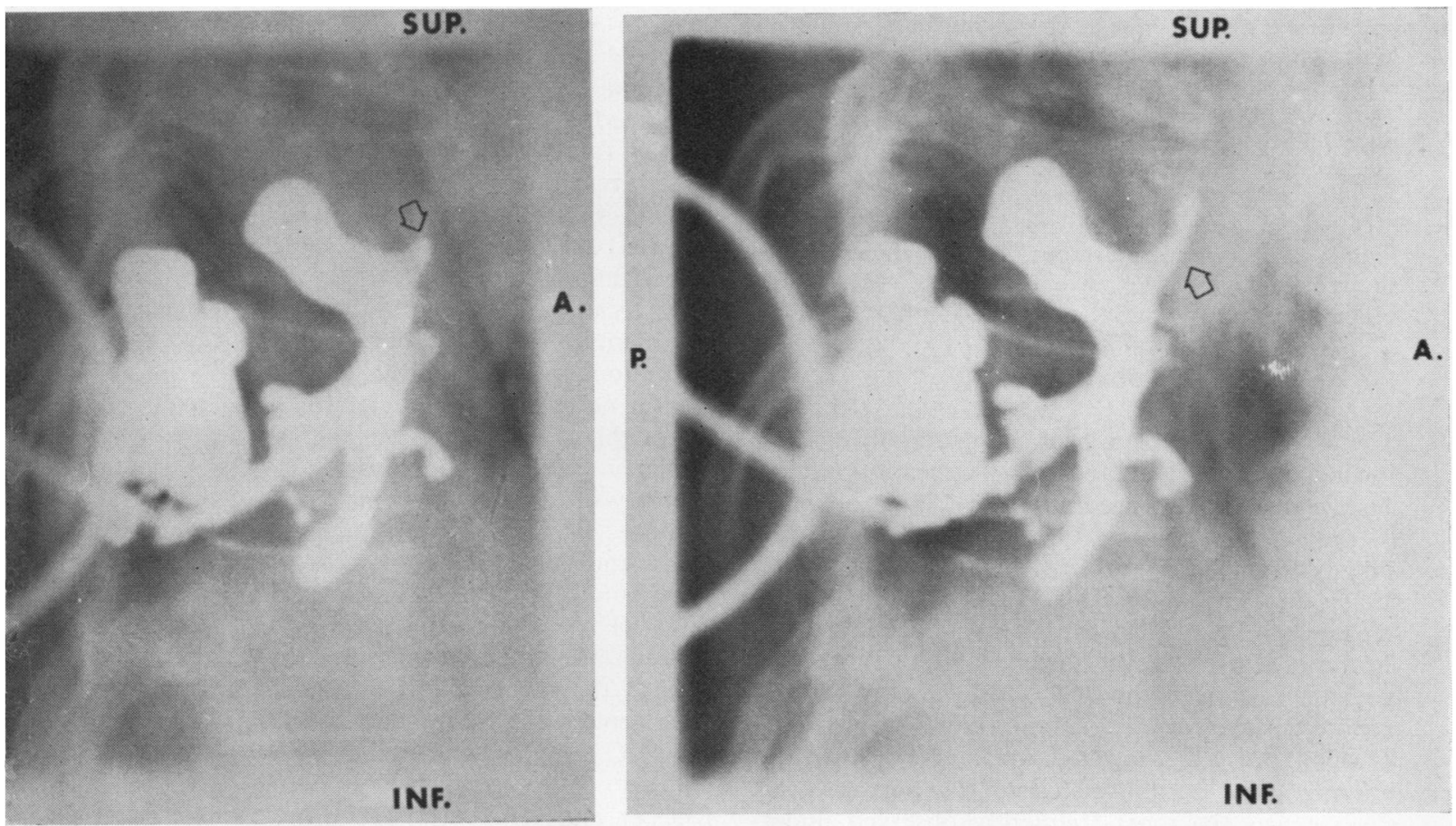

(a)

(b)

FIG. 4. Retrograde bronchogram. Right lateral decubitus projection $(a$ and $b):(a)$ Contrast material fills the pleural space and outlines an irregular cavity in the base of the right lung. The arrow marks the beginning of the bronchial communication. (b) The contrast material is shown entering a second degree bronchus. (c) The patient is rotated into a right oblique position. The arrows point to the lumen of the right lower lobe bronchus. On completion of this examination contrast material was expectorated in the patient's sputum.

(c)

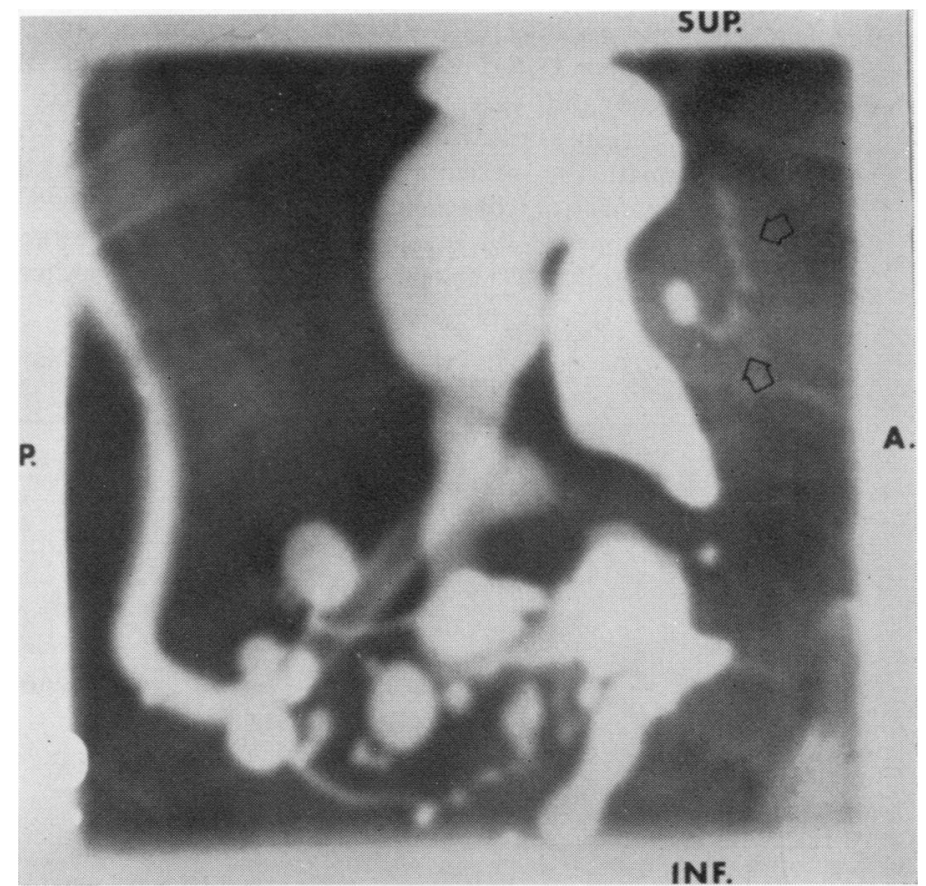

INE. 
patient was re-admitted in shock and died within an hour. The significant necropsy findings were generalized cardiomegaly with healed rheumatic thickening of the aortic, tricuspid, and mitral valves. There was no evidence of bacterial endocarditis. The main pulmonary arteries were occluded by laminated thrombi as far as the interlobular branches. Microscopic sections of the lungs showed organized thrombi in the lumina of medium-size arteries. The remaining organs showed evidence of passive congestion. The source of the pulmonary emboli was not demonstrated.

\section{DISCUSS:ON}

The development of a bronchopleural fistula following pulmonary infarction is unusual. Only 12 case reports have appeared since 1914, and none of the authors comments on the frequency of this phenomenon (Hayashi, 1914; Guggenheim, 1935 ; Marks, 1940 ; Chester and Krause, 1942 ; Rogers, 1946 ; Rawson and Cocke, 1947 ; Mundth, Foley, and Austen, 1965). When the present case is compared with those previously reported, the clinical similarities are striking (Table). All the infarcted areas were large, involving one or more lobes. Rheumatic heart disease was the most frequently observed underlying illness. Seven patients developed lung abscesses, five were infected and two were aseptic. Pneumothorax developed in all cases. Bronchopleural fistulae occurred two to 30 days after infarction, with an average time of 17 days.

In this series the initial acute illness began with the usual signs and symptoms of massive pulmonary infarction. Following a variable period of improvement the patients began to produce copious amounts of blood-tinged or purulent sputum, accompanied by fever, leucocytosis, and acute cardiac failure. This phase lasted several days to weeks and signified excavation of the infarcted area. After excavation there was usually a second period of quiescence before the patien developed a bronchopleural fistula which was usually fatal. Ten of the 13 patients died from acute respiratory insufficiency or intractable cardiac failure shortly after the pneumothoraxoccurred. There was no evidence of septicembolization in any case.

Bacterial invasion of the necrotic area may noe be essential for pulmonary cavitation or fistula formation to occur. Large infarcts may undergo aseptic necrosis and liquefaction (Soucheray and O'Loughlin, 1953 ; Bigger and Vermilya, 1936 ir Sweeney and Baggenstoss, 1949; Sandler: Matthews, and Bornstein, 1950 ; Coke and Dundee, 1955 ; Balchum and Zimmerman, 1952): Levin and Kernohan (1948) reported 23 abscesse $\tilde{}$ from among 550 cases of sterile pulmonary infarc tions. They excluded all cases of septicaemiacs wound infection, bronchopneumonia, and anye case of thrombophlebitis which displayed marked pain, tenderness, temperature greater than $101^{\circ} \mathrm{F}$ $\left(38.2^{\circ}\right.$ C. $)$, or marked leucocytosis. Bacteriologica culture of pathological material was sterile Chester and Krause (1942), using similar criteriå for case selection, found 17 sterile abscesses in 344 infarcts. In retrospect, in view of the blood stained, pathogen-free sputum our patient was producing early in her course, aseptic necrosif and liquefaction of the right lower lobe was occurring. After the area became infected excava tion was greatly accelerated.

The exact source of infection in our patient is unknown. The repeatedly sterile blood cultures tend to exclude a septicaemia, but a transient baci. teraemia could have occurred and been missed Alternatively, the organism could have diso

T A B L E

SUMMARY OF REPORTED CASES

\begin{tabular}{|c|c|c|c|c|c|c|c|c|c|}
\hline $\begin{array}{l}\text { Author } \\
\text { (year) }\end{array}$ & Sex & Age & $\begin{array}{l}\text { Underlying } \\
\text { Condition }\end{array}$ & $\begin{array}{c}\text { Embolic } \\
\text { Source }\end{array}$ & $\begin{array}{l}\text { Location } \\
\text { of Infarct }\end{array}$ & $\begin{array}{l}\text { Secondary } \\
\text { Infection }\end{array}$ & Cavitation & $\begin{array}{c}\text { Time of } \\
\text { Rupture (days) }\end{array}$ & $\begin{array}{c}\text { Immediate } \\
\text { Death }\end{array}$ \\
\hline $\begin{array}{cc}\text { Hayashi } & 1 \\
(1914) & 2 \\
\text { Guggenheim }\end{array}$ & $\begin{array}{l}\mathbf{M} \\
\mathbf{F}\end{array}$ & $\begin{array}{l}37 \\
40\end{array}$ & $\begin{array}{l}\text { RHD } \\
\text { RHD }\end{array}$ & $\begin{array}{l}\text { Heart } \\
\text { Leg }\end{array}$ & $\begin{array}{l}\text { RLL } \\
\text { RUL }\end{array}$ & $?$ & $\begin{array}{l}\text { No } \\
\text { No }\end{array}$ & $?$ & $\begin{array}{l}\text { Yes } \\
\text { Yes }\end{array}$ \\
\hline $\begin{array}{l}(1935) \\
\text { Marks } 1 \\
(1940) 2 \\
\text { Chester and } \\
\text { Krause (1942) } \\
\text { Rogers (1946) } \\
\text { Rawson and }\end{array}$ & $\begin{array}{l}\mathbf{F} \\
\mathbf{M} \\
\mathbf{M} \\
\mathbf{M} \\
\mathbf{M} \\
\mathbf{M}\end{array}$ & $\begin{array}{l}37 \\
17 \\
24 \\
66 \\
41 \\
44\end{array}$ & $\begin{array}{l}\text { ASHD } \\
\text { Colitis } \\
\text { RHD } \\
\text { ASHD } \\
\text { Lues } \\
\text { ASHD }\end{array}$ & $\begin{array}{l}\text { Heart } \\
\text { Leg } \\
\text { Leg } \\
\text { Leg } \\
\text { Leg } \\
\text { Heart }\end{array}$ & $\begin{array}{l}\text { RLL } \\
\text { LLL } \\
\text { RML } \\
\text { RLL,LUL } \\
\text { LUL } \\
\text { RLL,RML }\end{array}$ & $\begin{array}{l}\text { No } \\
\text { No } \\
\text { No } \\
\text { Yes } \\
\text { Yes } \\
\text { No }\end{array}$ & $\begin{array}{l}? \\
\text { Yes } \\
\stackrel{?}{\text { Yes }} \\
\text { Yes } \\
\text { No }\end{array}$ & $\begin{array}{r}12 \\
19 \\
18 \\
16 \\
28 \\
9\end{array}$ & $\begin{array}{l}\text { Yes } \\
\text { Yes } \\
\text { Yes } \\
\text { No } \\
\text { Yes } \\
\text { No }\end{array}$ \\
\hline $\begin{array}{c}\text { Cocke (1947) } \\
\text { Mundth } 1 \\
\text { et al. } 2 \\
\text { (1965) } 3 \\
\text { This paper }\end{array}$ & $\begin{array}{l}\mathbf{M} \\
\mathbf{M} \\
\mathbf{M} \\
\mathbf{M} \\
\mathbf{F}\end{array}$ & $\begin{array}{l}39 \\
49 \\
62 \\
36 \\
49\end{array}$ & $\begin{array}{l}\text { RHD } \\
\text { RHD } \\
\text { ASD } \\
\text { RHD } \\
\text { RHD }\end{array}$ & $\begin{array}{l}\text { Leg } \\
\text { Leg } \\
? \\
? \\
?\end{array}$ & $\begin{array}{l}\text { LLL } \\
\text { RLL } \\
\text { LLL } \\
\text { RUL } \\
\text { RLL }\end{array}$ & $\begin{array}{l}\text { No } \\
\text { Yes } \\
\text { Yes } \\
\text { Yes } \\
\text { Yes }\end{array}$ & $\begin{array}{l}\text { Yes } \\
\text { No } \\
\text { Yes } \\
\text { Yes } \\
\text { Yes }\end{array}$ & $\begin{array}{r}21 \\
3 \\
28 \\
2 \\
35\end{array}$ & $\begin{array}{l}\text { Yes } \\
\text { Yes } \\
\text { Yes } \\
\text { Yes } \\
\text { No }\end{array}$ \\
\hline
\end{tabular}

RHD $=$ rheumatic heart disease; ASHD = arteriosclerotic heart disease; ASD :s atrial septal defect; RLL - right lower lobe RUL = right upper lobe; $R M L=$ right middle lobe; LUL $=$ left upper lobe; LLL left lower lobe. 
seminated from the upper air passages downward to the infarcted area. In any event the infection was acquired in hospital between the tenth and twenty-third days.

Too few cases of this type have been reported to describe a specific therapeutic regime, but it seems as if routine supportive measures may not significantly influence the clinical course once the excavating process has begun. Prompt recognition of this complication and vigorous treatment with antibiotics is desirable in view of the high incidence of secondary infection with resultant rupture of the lung and death.

\section{REFERENCES}

Balchum, E. G., and Zimmerman, J. (1952). Pulmonary cavitation with negative sputum. Dis. Chest, 22,68 .

Bigger, I. A., and Vermilya, G. D. (1936). Aseptic infarct of the lung with sequestration. J. thorac. cardiovasc. Surg., 5, 315.

Chester, E. M., and Krause, G. R. (1942). Lung abscess secondary to aseptic pulmonary infarction. Radiology, 39, 647 .
Coke, L. R., and Dundee, J. C. (1955). Cavitation in bland infarcts of the lung. Canad. med. Ass. J., 72, 907.

Guggenheim, A. (1935). Pneumothorax par ouverture dans la plèvre d'un infarctus pulmonaire chez une cardiaque. Ann. Anat. path., 12, 872.

Hayashi, J. (1914). Über tötlichen Pneumothorax durch Infarkt und Emphysem. Frankfurt. Z. Path., 16, 1.

Levin, L., and Kernohan, J. W. (1948). Pulmonary abscess secondary to bland pulmonary infarction. Dis. Chest, 14, 218.

Marks, J. H. (1940). Pulmonary infarction as a cause of pneumothorax. New Engl. J. Med., 223, 934.

Mundth, E. D., Foley, F. D., and Austen, W. G. (1965). Pneumothorax as a complication of pulmonary infarct in patients on positive pressure respiratory assistance. J. thorac. cardiovasc. Surg. 50, 555 .

Rawson, A. J., and Cocke, J. A. (1947). Infarction of an entire pulmonary lobe with subsequent aseptic softening causing sterile hemopneumothorax. Amer. J. med. Sci., 214, 520.

Rogers, H. M. (1946). Bilateral pulmonary infarction and pneumothorax complicating hypertensive, coronary heart disease with myocardial infarction: Report of a case. Amer. Heart J., 32, 519. Sandler, B. P., Matthews, J. H., and Bornstein, S. (1950). Pulmonary
cavitation due to polyarteritis. J. Amer. med. Ass., 144, 754.

Soucheray, P. H., and O'Loughlin, B. J. (1953). Cavitation within bland pulmonary infarcts. Dis. Chest, 24, 180.

Sweeney, A. R., and Baggenstoss, A. H. (1949). Pulmonary lesions of periarteritis nodosa. Proc. Mayo Clin., 24, 35. 